\title{
A freshwater biodiversity hotspot under pressure - assessing threats and identifying conservation needs for ancient Lake Ohrid
}

\author{
G. Kostoski ${ }^{1}$, C. Albrecht $^{2}$, S. Trajanovski ${ }^{1}$, and T. Wilke ${ }^{2}$ \\ ${ }^{1}$ Hydrobiological Institute Ohrid, Naum Ohridski 50, 6000 Ohrid, Republic of Macedonia \\ ${ }^{2}$ Dept. of Animal Ecology \& Systematics, Justus Liebig University, Heinrich-Buff-Ring 26-32 IFZ, 35392 Giessen, Germany
}

Received: 21 May 2010 - Published in Biogeosciences Discuss.: 13 July 2010

Revised: 3 December 2010 - Accepted: 3 December 2010 - Published: 17 December 2010

\begin{abstract}
Immediate conservation measures for world-wide freshwater resources are of eminent importance. This is particularly true for so-called ancient lakes. While these lakes are famous for being evolutionary theatres, often displaying an extraordinarily high degree of biodiversity and endemism, in many cases these biota are also experiencing extreme anthropogenic impact.

Lake Ohrid, a major European biodiversity hotspot situated in a trans-frontier setting on the Balkans, is a prime example for a lake with a magnitude of narrow range endemic taxa that are under increasing anthropogenic pressure. Unfortunately, evidence for a "creeping biodiversity crisis" has accumulated over the last decades, and major socio-political changes have gone along with human-mediated environmental changes.

Based on field surveys, monitoring data, published records, and expert interviews, we aimed to (1) assess threats to Lake Ohrids' (endemic) biodiversity, (2) summarize existing conservation activities and strategies, and (3) outline future conservation needs for Lake Ohrid. We compiled threats to both specific taxa (and in cases to particular species) as well as to the lake ecosystems itself. Major conservation concerns identified for Lake Ohrid are: (1) watershed impacts, (2) agriculture and forestry, (3) tourism and population growth, (4) non-indigenous species, (5) habitat alteration or loss, (6) unsustainable exploitation of fisheries, and (7) global climate change.

Among the major (well-known) threats with high impact are nutrient input (particularly of phosphorus), habitat conversion and silt load. Other threats are potentially of high impact but less well known. Such threats include pollution with hazardous substances (from sources such as mines, former
\end{abstract}

industries, agriculture) or climate change. We review and discuss institutional responsibilities, environmental monitoring and ecosystem management, existing parks and reserves, biodiversity and species measures, international conservation activities, and ongoing research on conservation and raising of public awareness. Following this summary, we evaluate the status quo and future of Lake Ohrid and its biota. A comprehensive conservation strategy should include measures that result in an immediate reduction of nutrient input, particularly with phosphorus, in order to slow down the ongoing eutrophication process. The existing watershed management should become more effective. Implementation and particularly with a view to the enforcement of national laws should be enhanced. Increased research on the lakes' limnology, biodiversity, and conservation management practices are necessary. The latter research should identify conservation priorities. Public awareness should be enhanced. Facing these parallel needs to protect the unique biodiversity of Lake Ohrid, we suggest urging (a) implementation and enforcement of the General Management Plan that would ensure long-term integrated and sustainable use of the lake and its watershed, (b) scientific studies on ecology, biodiversity and effects of human impact, (c) the establishment of Core Conservation areas (CCA), including underwater reserves, and (d) Coastal Zone Management (CZM) areas that would constitute buffer zones for the CCAs around the lake. Given the number of identified threats, it is clear that only concerted international action can stop or at least slow down further degradation of Lake Ohrid and the creeping biodiversity crisis already evident. All conservation activities should, among others, ultimately lead to a trans-boundary major conservation area of the Ohrid-Prespa region that would allow long-term integration of both humans and nature. 


\section{Introduction}

It is generally accepted that humans are currently causing the greatest mass extinction of species since the disappearance of the dinosaurs some 65 million years ago (e.g., Thomas, J. A. et al., 2004; Cadotte et al., 2008). Some researchers suggest that if present trends continue, one half of all species will be extinct in less than 100 years due to, e.g., habitat destruction, pollution, invasive species, and climate change (Strauss and Pezold, 2009). It has been repeatedly emphasized that freshwater habitats and species living in freshwater are generally more prone to extinction than terrestrial or marine ones (Abell, 2002; Strayer, 2006). Immediate conservation measures for world-wide freshwater resources are thus of eminent importance (Dudgeon et al., 2006). There are, however, challenges to recognizing impacts of environmental changes and species responses such as extinction debt, that is, a delayed extinction of species following habitat loss or degradation (e.g., Kuussaari et al., 2009). Extinctions following environmental perturbations are more likely in specialized habitats (Glavin, 2007) and for highly endemic (Purvis et al., 2000) as well as ecologically specialized species (Norris and Harper, 2004). Such conditions prevail in so-called ancient lakes, that is, lakes that have continuously existed since before the last Interglacial (Albrecht and Wilke, 2008). While these lakes are famous for being evolutionary theatres, often displaying an extraordinarily high degree of biodiversity and endemism, in many cases these biota are also under extreme anthropogenic pressure (Coulter et al., 2006). Most of these lakes are subject to human-induced environmental and biotic change, including decline in population densities and loss of endemic species (Coulter et al., 2006). The degree of these changes, however, varies from lake to lake (Cohen, 1994; Cohen et al., 1996). Ancient lake endemics are particularly vulnerable to environmental changes due to their often small ranges, resulting in an imminent risk of extinction (e.g., Cohen, 1994). As a consequence of the biodiversity crisis in ancient lakes, the relative proportion of cosmopolitan species increases. In addition, newly introduced species have been recognized in an increasing number of ancient lakes, including famous large water bodies, which were thought to be largely inviolate such as Lake Malawi (Genner et al., 2008), Lake Titicaca (Albrecht et al., 2009b) or the Caspian Sea (Riedel et al., 2006).

Anthropogenic pressure is most often related to human population increase, as seen around the lakes of Sulawesi (von Rintelen and Glaubrecht, 2008) or the African Rift (Sturmbauer, 2008). Major environmental changes include reductions of water levels due to massive extraction for irrigation, fishery-related eutrophication, pollution, increasing seasonal climatic extremes, and toxification (Cohen, 1994). There is growing evidence that global change impacts ancient lakes and rapid warming, for example, recently has been registered in famous Lake Baikal (Moore et al., 2009).
Direct or indirect habitat destructions occur in these lakes. As a consequence, benthic communities are altered and eventually food webs become interrupted (Marijnissen et al., 2009). Highly adapted and specialized species often cannot cope with these sometimes rapid environmental changes (Noges et al., 2008).

Lake Ohrid, a major European biodiversity hotspot (Stanković, 1960), is a prime example for a lake with a magnitude of narrow range endemic taxa that are under increasing anthropogenic pressure. The transboundary lake is shared by the Former Yugoslav Republic of Macedonia (from hereon called Macedonia) and the Republic of Albania (from hereon called Albania). Taking surface area into account, Lake Ohrid is even considered to be one of the most diverse ancient lakes in the world with regard to the number of endemic species (Albrecht and Wilke, 2008). Lake Ohrid and its surroundings have been listed by UNESCO since 1979/1980 as "Natural and Cultural Heritage of the Ohrid region". Unfortunately, increasing evidence for a "creeping biodiversity crisis" has accumulated over the last decades (Tocko and Sapkarev, 1978; Wilke and Albrecht, 2007; Albrecht and Wilke, 2008), and major socio-political changes have gone along with human-mediated environmental changes (Watzin et al., 2002). These developments increase the need for a new comprehensive assessment of threats and respective conservation strategies for Lake Ohrid.

Based on field surveys and long-term observations, monitoring data available at the Hydrobiological Institute Ohrid (HBI), examining the extensive published record, and conducting expert interviews, we aim to:

1. assess threats to Lake Ohrids' (endemic) biodiversity,

2. summarize existing conservation activities and strategies, and

3. outline future conservation and research needs for Lake Ohrid.

\section{Threats}

The threat assessment carried out in this paper is based on the guidelines provided by both the International Union for Conservation of Nature (IUCN) and the Global International Waters Assessment (GIWA). The IUCN threat classification scheme was used, which is primarily designed to assess key threats to species. They involve past, ongoing and future threats, using a time frame of three generations or ten years, whichever is the longer (not exceeding 100 years in the future) as required by the Red List Criteria (IUCN, 2001). Environmental impacts were assessed using the scoring scheme provided by GIWA, which is more ecosystem oriented. Four impact scores ranging from 0 (impact unknown) through 1 (slight impact), 2 (moderate impact) to 3 (severe 
Table 1. Summary chart of IUCN threat classification scheme, key threats, current impact and expected future (mid-term) importance in the Ohrid basin. Four scores ranging from 0 (no know impact) through 1 (slight impact), 2 (moderate impact) to 3 (severe impact) were used to assess the current impact according to the scoring scheme provided by GIWA (2001). Average scores were calculated for each threat class and maximum values are also given. The level of knowledge regarding these threats is subjectively estimated. For details and references see text.

\begin{tabular}{|c|c|c|c|c|c|}
\hline Threat class & Key threat & Level of knowledge & Impact & Average impact & Maximum impact \\
\hline $\begin{array}{l}1 \text { Residential \& commercial } \\
\text { development }\end{array}$ & $\begin{array}{l}\text { 1.1 Housing \& urban areas } \\
\text { 1.2 Commercial \& industrial areas } \\
\text { 1.3 Tourism \& recreation areas }\end{array}$ & $\begin{array}{l}\text { well-known } \\
\text { moderately known } \\
\text { well-known }\end{array}$ & $\begin{array}{l}3 \\
1 \\
3\end{array}$ & $2(2.33)$ & 3 \\
\hline 2 Agriculture $\&$ aquaculture & $\begin{array}{l}\text { 2.1 Annual \& perennial non-timber crops } \\
\text { 2.2 Wood \& pulp plantations } \\
\text { 2.3 Livestock farming \& ranching } \\
\text { 2.4 Marine \& freshwater aquaculture }\end{array}$ & $\begin{array}{l}\text { less known } \\
\text { less known } \\
\text { less known } \\
\text { well-known }\end{array}$ & $\begin{array}{l}2 \\
1 \\
2 \\
2\end{array}$ & $2(1.75)$ & 2 \\
\hline $\begin{array}{l}3 \text { Energy production } \\
\& \text { mining }\end{array}$ & $\begin{array}{l}\text { 3.1 Oil \& gas drilling } \\
\text { 3.2 Mining \& quarrying } \\
\text { 3.3 Renewable energy }\end{array}$ & $\begin{array}{l}- \\
\text { moderately known } \\
-\end{array}$ & $\begin{array}{l}0 \\
3 \\
0\end{array}$ & 1 & 3 \\
\hline $\begin{array}{l}4 \text { Transportation \& service } \\
\text { corridors }\end{array}$ & $\begin{array}{l}\text { 4.1 Roads \& railroads } \\
\text { 4.2 Utility \& service lines } \\
\text { 4.3 Shipping lanes } \\
\text { 4.4 Flight paths }\end{array}$ & $\begin{array}{l}\text { less known } \\
- \\
- \\
-\end{array}$ & $\begin{array}{l}2 \\
0 \\
0 \\
0\end{array}$ & $1(0.5)$ & 2 \\
\hline 5 Biological resource use & $\begin{array}{l}\text { 5.1 Hunting \& trapping terrestrial animals } \\
\text { 5.2 Gathering terrestrial plants } \\
\text { 5.3 Logging \& wood harvesting } \\
\text { 5.4 Fishing \& harvesting aquatic resources }\end{array}$ & $\begin{array}{l}- \\
- \\
- \\
\text { well-known }\end{array}$ & $\begin{array}{l}0 \\
0 \\
0 \\
3\end{array}$ & $1(0.75)$ & 3 \\
\hline $\begin{array}{l}6 \text { Human intrusions \& } \\
\text { disturbance }\end{array}$ & $\begin{array}{l}\text { 6.1 Recreational activities } \\
\text { 6.2 War, civil unrest \& military exercises } \\
6.3 \text { Work \& other activities }\end{array}$ & $\begin{array}{l}\text { less known } \\
- \\
\text { less known }\end{array}$ & $\begin{array}{l}3 \\
0 \\
1\end{array}$ & $1(1.33)$ & 3 \\
\hline $\begin{array}{l}7 \text { Natural system } \\
\text { modifications }\end{array}$ & $\begin{array}{l}\text { 7.1 Fire \& fire suppression } \\
\text { 7.2 Dams \& water management/use } \\
\text { 7.3 Other ecosystem modifications }\end{array}$ & $\begin{array}{l}\text { less known } \\
\text { moderately known } \\
\text { less known }\end{array}$ & $\begin{array}{l}2 \\
2 \\
3\end{array}$ & $2(2.33)$ & 3 \\
\hline $\begin{array}{l}8 \text { Invasive \& other } \\
\text { problematic species \& genes }\end{array}$ & $\begin{array}{l}\text { 8.1 Invasive non-native/alien species } \\
\text { 8.2 Problematic native species } \\
\text { 8.3 Introduced genetic material }\end{array}$ & $\begin{array}{l}\text { moderately known } \\
- \\
\text { less known }\end{array}$ & $\begin{array}{l}2 \\
0 \\
2\end{array}$ & $1(1.33)$ & 2 \\
\hline 9 Pollution & $\begin{array}{l}\text { 9.1 Domestic \& urban waste water } \\
\text { 9.2 Industrial \& military effluents } \\
\text { 9.3 Agricultural \& forestry effluents } \\
\text { 9.4 Garbage \& solid waste } \\
\text { 9.5 Air-borne pollutants } \\
\text { 9.6 Excess energy }\end{array}$ & $\begin{array}{l}\text { well-known } \\
\text { moderately known } \\
\text { moderately known } \\
\text { well-known } \\
\text { less known } \\
-\end{array}$ & $\begin{array}{l}3 \\
3 \\
2 \\
3 \\
1 \\
0\end{array}$ & 2 & 3 \\
\hline 10 Geological events & $\begin{array}{l}\text { 10.1 Volcanoes } \\
\text { 10.2 Earthquakes/tsunamis } \\
\text { 10.3 Avalanches/landslides }\end{array}$ & $\begin{array}{l}- \\
- \\
-\end{array}$ & $\begin{array}{l}0 \\
0 \\
0\end{array}$ & 0 & 0 \\
\hline $\begin{array}{l}11 \text { Climate change } \& \text { severe } \\
\text { weather }\end{array}$ & $\begin{array}{l}\text { 11.1 Habitat shifting \& alteration } \\
\text { 11.2 Droughts } \\
\text { 11.3 Temperature extremes } \\
\text { 11.4 Storms \& flooding } \\
\text { 11.5 Other impacts }\end{array}$ & $\begin{array}{l}\text { well-known } \\
\text { less known } \\
\text { less known } \\
\text { less known } \\
\text { - }\end{array}$ & $\begin{array}{l}3 \\
3 \\
2 \\
1 \\
0\end{array}$ & $2(1.8)$ & 3 \\
\hline
\end{tabular}

impact) were used to quantify the importance of each key issue (Table 1). Details on determining impact scores can be found in the GIWA Methodology handbook for scaling and scoping (GIWA, 2001). Average scores were calculated for each threat class and maximum values are given. The level of knowledge regarding these threats was subjectively estimated.

Threats to the Lake Ohrid ecosystem are manifold, sometimes obvious in other cases rather subtle with the time frame for consequences ranging from immediate to longterm. In this paper, we compile threats to both specific taxa (and in cases to particular species) as well as to the lake ecosystems itself. These threats act on different spatial scales with varying intensities (Fig. 1). The list of current and particular potential threats assessed is of course incomplete and here we have restricted ourselves to anthropogenic threats, which may act in complex interconnected ways (Cohen, 1994). The amount of different and partly interacting 


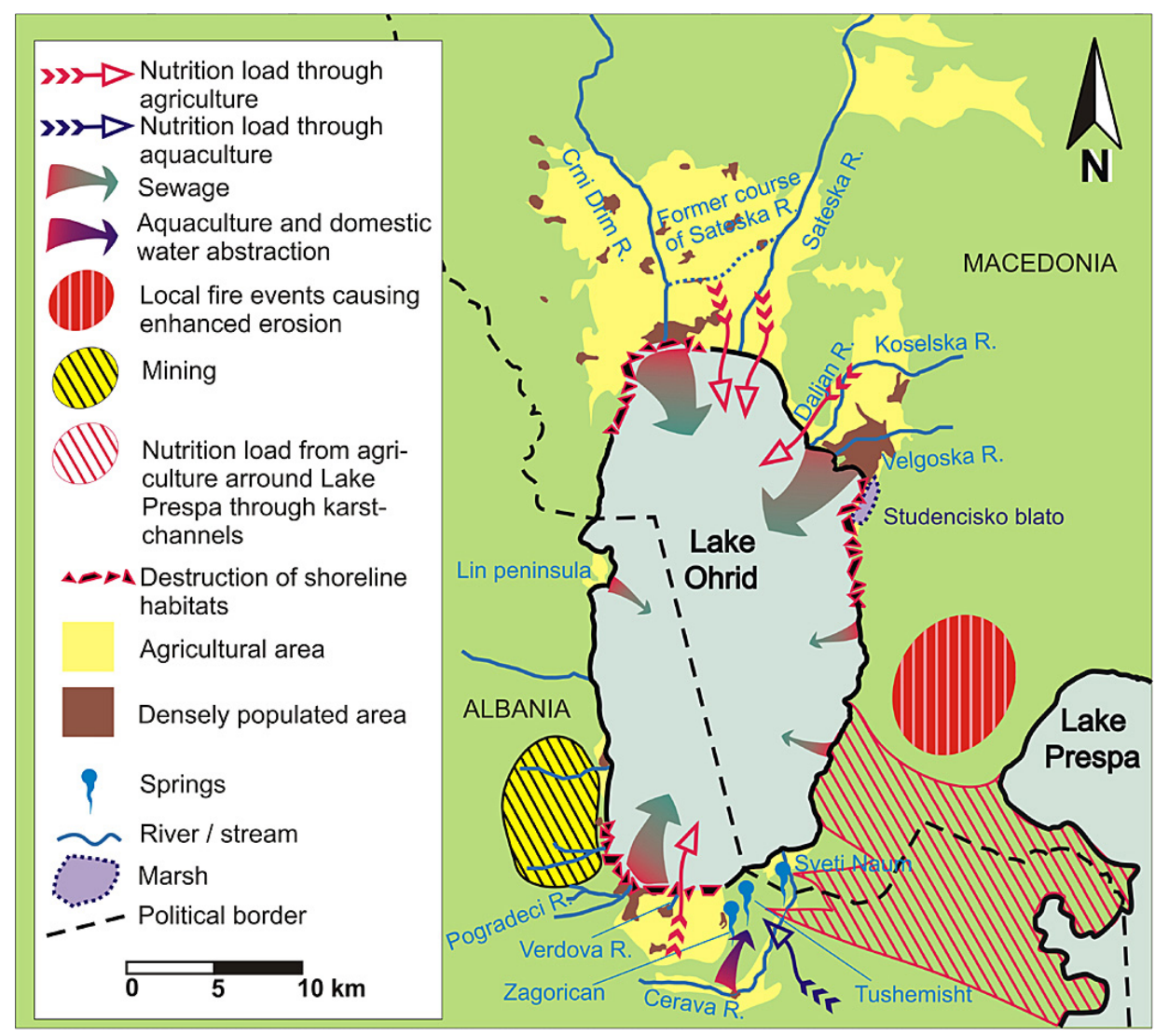

Fig. 1. Land use and spatial distribution of selected major threats to Lake Ohrid (for details see text and Table 1).

threats results in a number of conservation concerns related to Lake Ohrid: (1) watershed impacts, (2) agriculture and forestry, (3) tourism and population growth, (4) nonindigenous species, (5) habitat alteration or loss, (6) unsustainable exploitation of fisheries, and (7) global climate change. These concerns may include direct threats or may cause more indirect effects. Different spatial scales are involved, ranging from local to ecosystem wide scales. Threats assumed as basis in these concerns may be present on either of the sides of the lake (Albania, Macedonia) or be ubiquitous. Moreover, many of the threats listed in Table 1 affect more than one of the above concerns.

\subsection{Watershed impacts}

The natural tributaries of Lake Ohrid such as the Daljan, Velgoska, and Koselska rivers on the Macedonian side and the Cerava, Pogradeci, and Verdova rivers on the Albanian side carry anthropogenic nutrients and sediment loads (see Sect. 2.2) and thus pose a threat to oligotrophic Lake Ohrid (e.g., Vogel et al., 2010b). Most of those rivers flow through populated areas with nonexistent or inefficient sewage treatment systems.
The River Sateska was diverted into Lake Ohrid from its former path into the River Crni Drim in 1962 (Fig. 1) in order to improve the water balance of the lake and to enhance its potential for hydropower use. Since then, however, it has been a major source of biochemical oxygen demand (BOD) and sediments fed into the lake (Jordanoski et al., 2006; Vogel et al., 2010b). Long-term microbiological as well as physico-chemical investigations revealed the adverse effects of the Sateska inflow on Lake Ohrid (Watzin et al., 2002).

Water abstraction is currently considered to be of minor importance in Lake Ohrid (Matzinger et al., 2006a, b), partly because annual balance is achieved by regulating the affluent Crni Drim River and the diversion of the Sateska River. It is, however, a major problem in neighboring Lake Prespa (Fig. 3). Given the underground hydraulic karstic connection between these two lakes, several studies have investigated the impact of Lake Prespa waters on Lake Ohrid (e.g., Amataj et al., 2007). It was concluded that the phosphorus transported from eutrophicated Lake Prespa may jeopardize Lake Ohrid in the future (Matzinger et al., 2006a). Increased phosphorus concentrations were identified in Lake Ohrid, which facilitate the process of eutrophication (Matzinger et al., 2007) and which pose a serious threat to hypolimnetic dissolved oxygen - the major prerequisite for sublittoral and profundal endemic life (Stanković, 1960). 
Karstic springs such as those in Sv. Naum, Zagorican, and Tushemisht also have a major impact on the water balance, temperature regime, and oxygen supply of Lake Ohrid. These springs are some of the most affected water bodies in the Ohrid basin. Negative impacts are most obvious in the Zagorican/Tushemisht feeder spring complex on the Albanian side. This is of major importance since these karstic springs are responsible for a large part of the water balance of Lake Ohrid and thus directly impact the lake. Since the mentioned feeder springs are linked to Lake Prespa via underground connections, eutrophication processes there impact Lake Ohrid through these sources (Matzinger et al., 2006a). Touristic facilities and ongoing capturing and pollution of the springs are also of great concern. The springs are not only very important from a hydrological point of view, they also harbour several endemic species (Albrecht and Wilke, 2008).

Domestic and industrial waste waters pose another major threat to Lake Ohrid. Approximately $65 \%$ of the wastewater in Macedonia is currently collected and transported to the treatment plant Vranista (Avramoski et al., 2003, 2006) However, the ring collecting system for domestic sewage installed in the late 1980s on parts of the Macedonian side is partly disfunctional (D. Georgiev, personal communication, 2009). By the end of 2010, the third project phase of the Pogradec waste water treatment project will start. Population growth (see below), and rapid urbanisation in both Albania and Macedonia provide a major source of sewage water, which flows into Lake Ohrid. So-called "black spots", characterized by high contamination with bacteria have been identified around densely populated areas (Fig. 1), such as around Pogradec (Watzin et al., 2002).

Besides untreated domestic sewage, which is a wellknown threat, there have been major inflows of toxic sewage from the textile industry in Ohrid (OTEX), electrogenerator fabrics (EMO), and Zastava car parts galvanization facilities. Economic reasons have forced the closure of many plants in the past two decades and thus these sources of major pollution have been greatly reduced. A recent study has found high PCB concentrations in edible fish of Lake Ohrid (Topi et al., 2010). Heavy metal contaminations from, for example, $\mathrm{Cr}$ or $\mathrm{Fe}-\mathrm{Ni}$ mines on the Albanian side, however, remain a major problem with unforeseeable long-time consequences to be caused by waste flowing into the lake (Watzin et al., 2002). These specific sources of contamination can be traced in the sediments (Vogel et al., 2010b). Remaining stockpiles also present a permanent threat to Lake Ohrid, particularly large waste dumps close to the shore (Watzin et al., 2002). Moreover, though mining and metal processing has been reduced in the past years, this may only be temporary (Fig. 2e). The extent and overall importance of the industrial contaminations, e.g., with metals, are not well understood.

Solid waste washed into the lake (Fig. 2g) is another problem as sanitary landfills, for example in Bukovo/Koselska or at Tushemisht, are rare or do not meet modern standards. Trash dumped into the lake accumulates over the years and eventually habitats become altered. Long-term effects of rotten plastics cannot be estimated for the time being.

\subsection{Agriculture and forestry}

Land use changes and particularly intensified agriculture in the Ohrid watershed are a major concern, and their impacts are of potentially great importance to the Lake Ohrid ecosystem (Watzin et al., 2002). Agriculture is carried out on many areas, particularly in the north and southwest of the Ohrid basin (Fig. 1). The extent and severity of the impacts, however, are less well known (Table 2). A negative example of the effects of agricultural activities in the surrounding areas is provided by the complete draining of Lake Maliq in Albania (Fig. 2f) approximately 80 years ago (e.g., Dénèfle et al., 2000). Today, the intensive use of fertilizers and overuse of pesticides is believed to directly affect the eutrophication process in Lake Ohrid. Irrigation in much of the watershed should increase the problem. The Annual Monitoring Report carried out by the Environmental Institute in 2005, 2006, and by the Environment and Forest Agency (Monitoring laboratory of Pogradec) in the year 2007, shows that the use of chemical fertilizers from 1998 until 2007 has increased progressively (Supreme Audit Institution, 2008).

Many pesticides are used, including copper sulfate, lindane, organophosphates, synthetic fungicides, and others (UNESCO ROSTE, 2004). For example, $8901 \mathrm{~kg}$ of pesticides were used in the Pogradec district of Albania in the year 2001 (UNESCO ROSTE, 2004). In Macedonia, agrochemicals are regulated, but many banned substances are readily available on the black market. However, statistics on pesticide use do not exist (UNESCO ROSTE, 2004; Watzin et al., 2002).

Pesticides accumulate in the Lake Ohrid fish and thus pose a real health hazard to humans consuming them (UNESCO ROSTE, 2004). Other major impacts of agriculture/forestry are disruption of formerly interacting lake/watershed habitats due to land use, increased sediment loads and erosion due to deforestation of nearby areas, and lake-level changes due to water extraction. The latter may be less directly important for Lake Ohrid, but constitutes a major issue for Lake Prespa, where huge amounts of water are abstracted every year for plantations mainly on the Macedonian and Greek sides. Given the underground connection between lakes Prespa and Ohrid, water level changes in Lake Prespa likely, however, impact the water balance of Lake Ohrid as well.

Logging and subsequent surface erosion into Lake Ohrid are causes for concern. Though its effects are less wellknown, it is a constantly increasing phenomenon. For example, a major silt load mainly caused by deforestation along the course of River Sateska is impacting the littoral around the mouth (N. Hoffmann, personal communication, 2010; Vogel et al., 2010b) (Fig. 2h). Concerns also exist for human mediated large scale fire events (Fig. 1), which by far exceed 

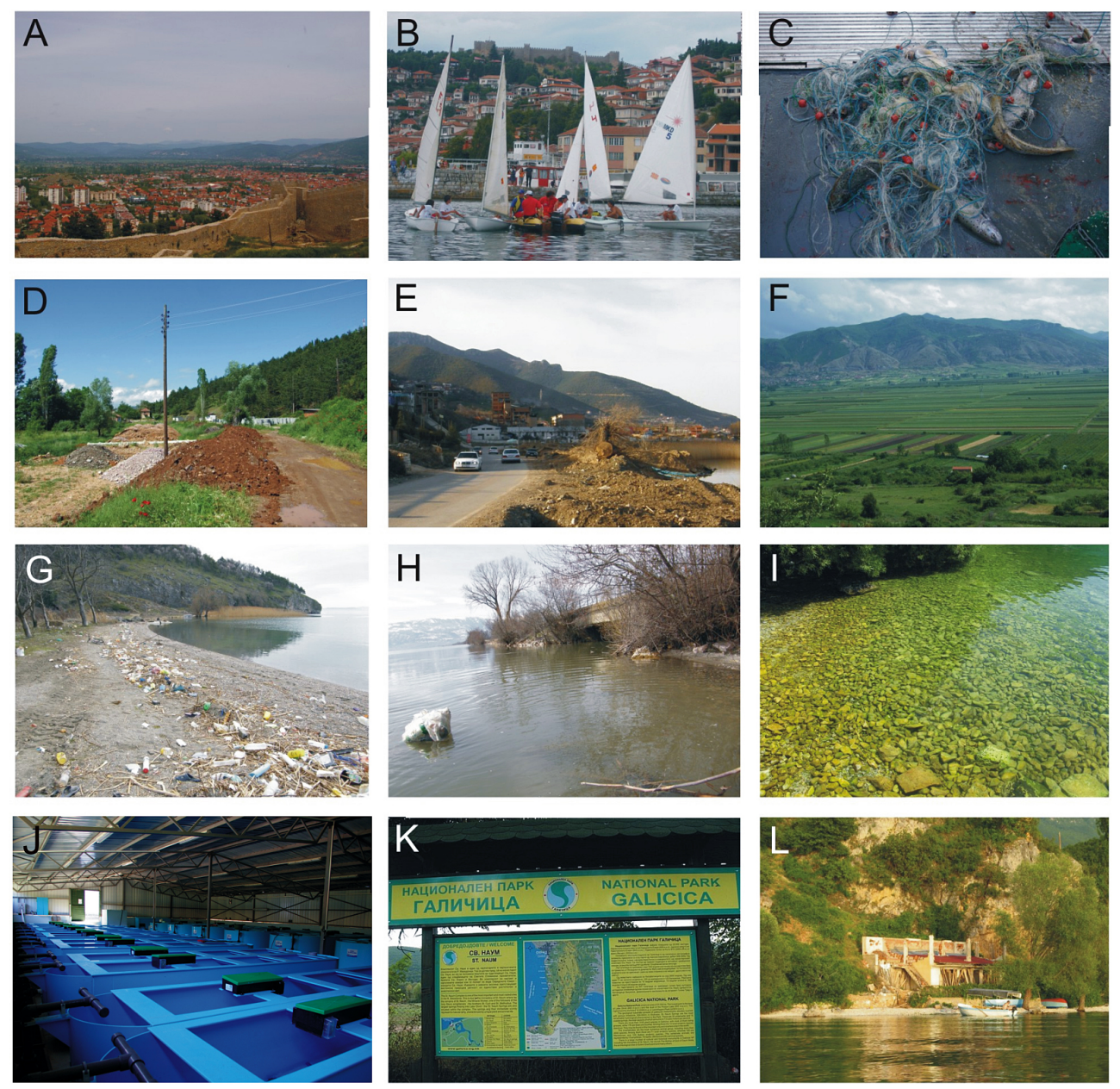

Fig. 2. Examples of threats facing Lake Ohrid and conservation activities. (A) - Urban and rural expansion in the Ohrid basin, Ohrid town; (B) - increasing boat traffic on the lake; (C) - overexploitation of fisheries, illegal net fishing on Macedonian side; (D) - habitat loss, Bej Bunar spring NW of Ohrid, type locality of an endemic spring snail; (E) - destruction of shoreline habitats N of Pogradec, Nickel Chromium processing facilities in the background; $(\mathbf{F})$ - intensively used agricultural areas in the Lake Ohrid surroundings as sources of nutrient, pesticide, herbicide and sediment input, Maliq region, Albania; (G) - solid waste pollution, plastics at beach near Grasnica; (H) - diverted Sateska river as major source of sediment, organic and chemical pollution; (I) - eutrophication as indicated by increased algal growth in the littoral; $(\mathbf{J})$ - species survival program for Ohrid trout including hatcheries and co-ordinated release, combined with fishing ban on Macedonian side; (K) - National Park Galicica with strictly protected zones at Lake Ohrid shore and feeder spring system Sv. Naum.; (L) - removal of illegal houses in the strictly protected zone on the Lake Ohrid shore.

natural events in both intensity and frequency (D. Georgiev, personal communication, 2009). Wood processing plants, particularly along the Albanian shore are another significant source of contamination with wastewater in Lake Ohrid (Watzin et al., 2002).

\subsection{Tourism and population growth}

Though the shores of Lake Ohrid might have been populated for thousands of years (Holtvoeth et al., 2010), over the past decades three lakeside towns - Ohrid, Struga, and Pogradec - have grown considerably with a combined population approaching 200000 in 2008 according to the State Statis- tical Offices of Macedonia and Albania (GeoHive, 2010; Fig. 2a). The growing number of both permanent residents and tourists is a major problem in the Lake Ohrid area, with increasing pollution being the most serious associated threat. Political instability following the breakup of Ex-Yugoslavia greatly reduced the number of tourists frequenting the lake (UNESCO ROSTE, 2004). The last few years, however, have seen an increase in tourist numbers both in Macedonia and Albania. For the Macedonian part, 250000 tourists have been counted in the year 2007 (Southeast European Times, 2007). The number of weekend houses, hotels, beaches with tourist facilities, sports recreational areas, campsites, and resorts is rising rapidly, mainly around the Macedonian towns 
Table 2. Conservation concerns and associated major threats identified for Lake Ohrid. The level of knowledge regarding these threats is subjectively estimated. Examples are provided for each threat (for details see text).

\begin{tabular}{|c|c|c|c|c|}
\hline Conservation concern & Major threats & Level of knowledge & Example & Reference \\
\hline \multirow[t]{4}{*}{1 Watershed impacts } & Nutrient input & well-known & $\begin{array}{l}\text { Sateska River, Lake Prespa } \\
\text { underground connection }\end{array}$ & $\begin{array}{l}\text { Watzin et al. (2002); } \\
\text { Matzinger et al. (2007) }\end{array}$ \\
\hline & Increased sediment load & moderately known & Tributaries to Lake Ohrid & Vogel et al. (2010b) \\
\hline & Waste water & well-known & Domestic waste waters & Watzin et al. (2002) \\
\hline & Metal contamination & less known & Industries and disposals Albania & Vogel et al. (2010b) \\
\hline \multirow[t]{5}{*}{2 Agriculture and forestry } & Intensified agriculture & less known & Pesticides in fish & UNESCO ROSTE (2004) \\
\hline & Irrigation & less known & $\begin{array}{l}\text { Northern plains of the } \\
\text { Ohrid basin }\end{array}$ & Watzin et al. (2002) \\
\hline & Logging & less known & Wood processing plants Albania & Watzin et al. (2002) \\
\hline & Water abstraction & less known & $\begin{array}{l}\text { Agribusinesses around Lake } \\
\text { Prespa, thus affecting the water } \\
\text { regime of Lake Ohrid }\end{array}$ & This study \\
\hline & Fire events & less known & $\begin{array}{l}\text { Anthropogenic fires on Galicica } \\
\text { Mountains }\end{array}$ & $\begin{array}{l}\text { D. Georgiev, personal } \\
\text { communication (2010) }\end{array}$ \\
\hline \multirow[t]{3}{*}{$\begin{array}{l}3 \text { Tourism and population } \\
\text { growth }\end{array}$} & $\begin{array}{l}\text { Construction of houses and } \\
\text { facilities }\end{array}$ & moderately known & $\begin{array}{l}\text { Weekend houses on slopes } \mathrm{E} \text { of } \\
\text { Ohrid town }\end{array}$ & This study \\
\hline & $\begin{array}{l}\text { Speed boats water scooters } \\
\text { etc. }\end{array}$ & less known & $\begin{array}{l}\text { Disturbance of spawning grounds } \\
\text { of cyprinid fishes }\end{array}$ & $\begin{array}{l}\text { Z. Spirkovski, personal } \\
\text { communication }(2010)\end{array}$ \\
\hline & Pollution & well-known & $\begin{array}{l}\text { Bacterial pollution in front } \\
\text { of Pogradec }\end{array}$ & Avramoski et al. (2006) \\
\hline \multirow[t]{2}{*}{4 Non-indigenous species } & $\begin{array}{l}\text { Competition for native } \\
\text { species }\end{array}$ & less known & $\begin{array}{l}\text { Rainbow trout as competitor for } \\
\text { Ohrid trout }\end{array}$ & \\
\hline & Community changes & less known & $\begin{array}{l}\text { Elodea canadensis in } \\
\text { macrophytic communities }\end{array}$ & \\
\hline \multirow[t]{5}{*}{5 Habitat alteration or loss } & Destruction coastal habitat & well-known & $\begin{array}{l}\text { Wetland loss (e.g., Studencisko } \\
\text { blato) }\end{array}$ & \\
\hline & $\begin{array}{l}\text { Fragmentation of macro- } \\
\text { phytic littoral communities }\end{array}$ & moderately known & $\begin{array}{l}\text { Macrophyte belt near } \\
\text { Pestani/Trpejca }\end{array}$ & Trajanovska (2009) \\
\hline & $\begin{array}{l}\text { Spring conversion and } \\
\text { capture in Ohrid basin }\end{array}$ & moderately known & $\begin{array}{l}\text { Sum Spring, partly } \\
\text { Tusemisht/Zagorican complex }\end{array}$ & This study \\
\hline & Spring destruction & well-known & $\begin{array}{l}\text { Destruction Bej Bunar } \\
\text { spring/Ohrid town }\end{array}$ & This study \\
\hline & Eutrophication & well-known & $\begin{array}{l}\text { Changing microfilm and algae } \\
\text { communities on rocky shores }\end{array}$ & This study \\
\hline \multirow{2}{*}{$\begin{array}{l}6 \text { Unsustainable } \\
\text { exploitation of fisheries }\end{array}$} & Overfishing & well-known & Illegal fish catch & UNESCO ROSTE (2004) \\
\hline & Release of non-native fish & well-known & Seven species of non-native fish & Talevski et al. (2010) \\
\hline 7 Global change & $\begin{array}{l}\text { Increasing average } \\
\text { temperatures }\end{array}$ & less known & $\begin{array}{l}\text { Amplification of eutrophication } \\
\text { with subsequent anoxia in many } \\
\text { parts of the lake }\end{array}$ & Matzinger et al. (2007) \\
\hline
\end{tabular}

of Ohrid and Struga. Particularly the Albanian side has seen a rapid expansion of permanently inhabited settlements, and an explosion of the population living in Pogradec after the former communist system collapsed (GEF, 1997). Since then, bacterial pollution has increased tremendously in this area (Watzin et al., 2002). These developments are not controlled by any western European standards and many impacts on the lake ecosystem will only become evident at a later date. Slopes in the catchment area have become densely populated as well, which undoubtedly will affect the hydrological conditions. More importantly, even pristine coastal areas, which are highly sensitive and of great importance for point endemic species (Hauffe et al., 2010), are increasingly under pressure due to the construction of (often illegal) houses and 


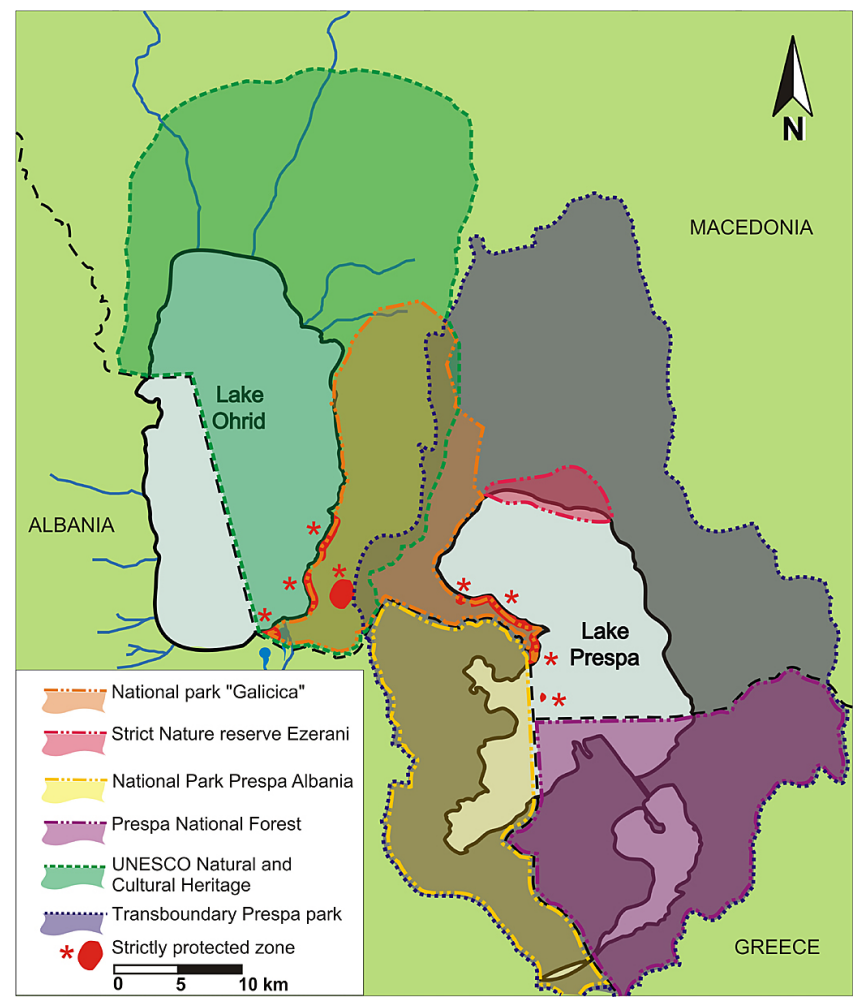

Fig. 3. Conservation areas in the transboundary Ohrid Prespa lakes region. Within Galicica National Park, strictly protected zones are shown only (Veli Dab area and Sv. Naum at Lake Ohrid). Note that the Pelister National Park (Macedonia) has been omitted.

boat facilities. Unfortunately, the immediate effects of the latter threats are not easy to estimate. However, given the experience from other lakes worldwide, one would expect multi-fold negative impacts.

Another major problem is increasing boat traffic, which allows people to readily reach the even most remote parts of the lake. Waves from speed boats and water scooters, for example, are known to be destructive to littoral communities and even adjacent wetland ecosystems (e.g., Schmieder and Pier, 2000). These waves are caused in addition to natural waves and are concentrated in the summer times (touristic season), when natural waves are rather moderate. Disturbances affect the return of the spawning fishes to their natural and long existing spawning grounds and, at the same time, decrease the number of potential spawners and the extent of existing spawning areas. This is very important for endemic cyprinid fish species, which spawn at exactly the same time as when there are maximum numbers of tourists in these areas (Spirkovski and Ilic-Boeva, 2004). Noise emissions certainly impact breeding birds and spawning shallow water fishes. In addition to noise emission resulting from sport boating there is also a permanent danger of pollution. Regulations concerning private boat traffic do not yet exist (Fig. 2b).

\subsection{Non-indigenous species}

Non-indigenous species become more important in ancient lake ecosystems, particularly with ongoing human disturbance (Stift et al., 2004; Albrecht et al., 2009b; Heiler et al., 2010). In Lake Ohrid, exotic fishes like the rainbow trout and the silver carp have been introduced decades ago (Serafimova, 1985) and at least seven such species can be found today (Talevski et al., 2010). The rainbow trout is a particular concern, since it might be able to displace the native Ohrid trout. The impact of these and other fish species introductions have not been studied adequately. Therefore the introduction of fish diseases cannot be ruled out. Changes in zooplankton communities are evident with recent invasions of crustacean species such as Diaphanosoma brachiurum and Leptodora kintii, which prefer warmer water bodies. This could potentially be related to an increasing average water temperature in Lake Ohrid (Kostoski et al., 2004).

The lake has also witnessed the introduction of nonindigenous macrophytes such as Elodea canadensis as early as 1957 (Ministry of Environment and Physical Planning, 2003). The introduction took place via the Studencista Canal close to Biljanini Spring. After a short period, this species was reported in the Sveti Naum and Sum springs and along the River Drim. Interestingly, this notorious pest species has not been recorded recently (S. Trajanovska, unpublished data, 2009).

In general, Lake Ohrid appears to harbour far fewer invasive species than other Balkan Lakes (Albrecht et al., 2009a). It is, however, obvious that highly impacted littoral parts such as the Ohrid Bay or areas near the Lin Peninsula have lately become home to several non-indigenous gastropod species (Albrecht et al., 2010 ${ }^{1}$ ). The number of observations of nonindigenous species will probably rise in the coming years and such species should be carefully monitored (e.g., Wilke et al., 2010).

\subsection{Habitat modification}

The significant alteration or even loss of habitats as one of the best understood conservation concerns is an ongoing problem in and around Lake Ohrid, mainly associated with expansion of settlements around the major towns Ohrid, Struga, and Pogradec (Fig. 1). It is among the most studied and best understood concerns (Table 2). The construction of building, boating facilities (often concrete constructions), beaches and other touristic facilities is a major factor in this context, but also private weekend houses have directly contributed to the alteration of mainly coastal habitats (see above; also see Fig. 21). Some of these coastal habitats have been destroyed (Fig. 2e) and the reed belts adjacent to the lake have become severely reduced. Unique macrophyte communities around Lake Ohrid have been altered by shoreline manipulations and

\footnotetext{
${ }^{1}$ Albrecht, C., Hauffe, T., Schreiber, K., and Wilke, T.: unpublished data, 2010 .
} 
nutrient enrichment (Watzin et al., 2002). Changes, fragmentation and complete destruction of macrophyte associates are evident in several parts of the lake (Trajanovska, 2009). As a result of this negative influence, new macrophyte associations develop in some locations (e.g., near Trpejca and Pestani), and fish spawning grounds in these regions may convert from salmonid into cyprinid spawning grounds (Spirkovski and Ilic-Boeva, 2004).

Adjacent wetland habitat destruction is particularly obvious in the northwestern (Strusko pole) and northeastern region (Studencisko blato, southeast of Ohrid town). Due to the intensive conversion of wetlands into agricultural areas, melioration, and soil sealing, the terrain has been drained. Moreover, the destruction of the wetland Studencisko blato caused a decrease of the distribution range of some relic wetland plant associations, which have now become strictly limited to a few small parts of Studencisko blato (Ministry of Environment and Physical Planning, 2003).

Many of the karstic springs in the basin have been tapped for drinking water like the Sum Spring north of Lake Ohrid. Other springs like Bej Bunar northwest of Ohrid town, which is the type locality of an endemic spring snail taxon, have recently been destroyed completely by road construction (Fig. 2d).

Processes like eutrophication more indirectly contribute to the alteration of habitat through, for example, changes in the microfilm and algae communities on rocky substrate (Fig. 2i). Many of those changes happen over long periods (cf. Matter et al., 2010; Wagner et al., 2010) and are difficult to trace since most often data on the former states of habitat are not available. In deeper habitats like the sublittoral or even the profundal, technical difficulties have hampered a comprehensive monitoring of such potential changes.

\subsection{Unsustainable fisheries}

A major impact for the ecosystem has been overfishing particularly of the Ohrid trout (Salmo letnica) but also the belvica (Salmo ohridana). There are still no control measures on the Albanian side and illegal fishing on the Macedonian side prevails (Fig. 2c). Erroneous management and stocking practices have also impacted the population structure of the Ohrid trout (Szymanczak et al., 2009). A major decline in fish catch has been stated not only for these salmonids but also for carp and bleak. An association for Fishery Management has been established in Pogradec only in 2002 (UNESCO ROSTE, 2004).

The golden trout (Oncorhynchus mykiss aguabonita) seems to have become a further threat to the native Ohrid trout since it was found in the fish catch both in the lake and in the springs of Sv. Naum (Z. Spirkovski, personal communication, 2010).

\subsection{Climate change}

Climate change appears to be the threat that is most difficult to assess and least understood. However, evidence has been accumulated for a causal link of species extinctions and re-current climate changes (e.g., Thomas, C. D. et al., 2004; Secretariat of the Convention of Biological Diversity, 2009). Monitoring results into both the limnological characteristics as well as correlated faunal change accumulated circumstantial evidence for changing ecological conditions in Lake Ohrid that might at least partly be attributed to global warming (Mankolli and Peculi, 2010).

Valuable studies in this context have been conducted by the EAWAG, Switzerland that addressed the sensitivity of Lake Ohrid to global warming (Matzinger et al., 2007). These studies revealed that global warming amplifies the detrimental effects of increased nutrient inputs into Lake Ohrid (see above). Subtle effects of decreased vertical mixing and less frequent complete deep convections potentially caused by global warming have been demonstrated for the sensitive hypolimnetic dissolved oxygen (see also Vogel et al., 2010a). Eutrophication also amplifies this effect and anoxia has been predicted by the end of the century if phosphorus load remains constant and warming predictions hold true (Matzinger et al., 2007).

\subsection{Other threats}

There are other threats to the lake on various scales like acid rainfall, ash pollution from households and industrial plants, and runoff from nearby roads (Fig. 2e). Traffic jams along the coastal roads increase the emission of car gasses and represent a risk factor for the lake due to runoff of heavy metals, polycyclic aromatic hydrocarbon and oil. Sealing of open soil along the shoreline for various construction activities may foster runoff processes into the lake. These threats will likely increase in the near future. There are unpredictable threats such as a major boat accident with subsequent pollution (as has happened in 2009). Boat accidents might be very important, e.g., for restricted endemic species.

\subsection{Status quo and future of Lake Ohrid and its biota}

Based on the IUCN threat classification scheme, key threats, current impact and expected future (mid-term) importance in the Ohrid basin were determined. Of the 11 threat classes scored (Table 1), only geological events are currently scored with an impact value of 0 . Five threat classes have on average slight impact (1) and five classes have moderate impact (2). These latter threat classes are residential \& commercial development, agriculture \& aquaculture, natural system modifications, pollution, and climate change \& severe weather. Note that some of the threat classes with a current average impact score of only 1 or 2 may still contain singular or multiple threats with severe impacts ( 8 of the 11 threat 
classes, see Table 1). The level of knowledge regarding these threats varies and is thus subjectively estimated according to the general methodological approach outlined above. Table 2 lists examples of threats related to the major conservation concerns previously discussed.

Given the variety of threats Lake Ohrid is facing, their complex interaction, and temporal and spatial explicit nature, consequences for ecosystems and biota are difficult to assess. Some consequences are subtle, others are subject to a time lapse, yet others are already observable. Among the latter, habitat destruction, decline of populations, and shifts in species composition are the most obvious. It should, however, be noted that some of these effects have been visible for decades. Changes in the abundance of major macrozoobenthic taxa as a result of environmental change, for example, was already observed 35 years ago (Tocko and Sapkarev, 1978) and continues to occur (Trajanovski, 2005). The general benthic composition in the profundal of the lake has changed and the depth range of the Dreissena beds has shrunk (Trajanovski, 2005).

Benthic algal blooms and related increases in opportunistic algal-feeding minnow populations were reported as early as 1978 (Taylor and Gerking, 1978). The fish community of Lake Ohrid has changed significantly (e.g., Talevski et al., 2010), consequences for the ecosystem integrity are not yet studied. The alteration of the traditional spawning grounds due to Phragmites belt reductions and alteration of adjacent wetland habitats are of importance for many native fish species in the lake.

In contrast, species loss is difficult to prove, but evidence exist that shows that some profundal gastropod species have become extremely rare (Hauffe et al., 2010). Decline of populations has been recognized from long-term studies on biomass distributions of major macrozoobenthic groups (Trajanovski and Budzakoska, 2002). A comparative study on the present status of the charophyte flora has shown that 5 species described in 1936 were not registered during recent extensive investigations (Trajanovska, 2009). The decline in water quality around the tributary mouths and heavily populated littoral areas has been recorded by the HBI monitoring program (Jordanoski et al., 2004; Lokoska et al., 2004). Signs of eutrophication are already obvious, demonstrated by increased algal covers of littoral karstic rocks, even in remote parts of the lakes (Fig. 2i). The complex interplay of dissolved oxygen content and increased phosphorus loads has been described (Matzinger et al., 2007).

Rapidly increasing habitat alterations will further reduce suitable habitats for endemic organisms that are partly restricted to very small areas within the lake. Moreover, the number of non-indigenous and eventually invasive species will likely rise in the upcoming years. This can in part be related to direct human activities (see Sect. 1).

Overall, it is clear from the above assessment that Lake Ohrid is currently facing both an ecosystem and a creeping biodiversity crisis. This is complicated by the complex set- ting and limnological features of the lake "s basin and the considerable delay of effects of impacts on the ecosystem. The outlined conservation concerns together with proven and predicted consequences have led to a variety of activities that aim at protecting Lake Ohrid and its biota.

\section{Activities concerning Lake Ohrid protection}

\subsection{Institutional responsibilities}

A number of institutions at Lake Ohrid are concerned with conservation issues. In Macedonia, there are several ministries responsible for protection of biodiversity and environment. The Ministry for Environment and Physical Planning hosts a local unit for the protection of Lake Ohrid (now Bilateral Board for protection of Lake Ohrid), which manages the realization of the projects for the protection of Lake Ohrid and its watershed. The National Park authorities of the Galicica Park act on the behalf of the Ministry of Environment and Physical Planning.

The Hydrobiological Institute Ohrid (HBI) belongs to the Ministry of Education and Sciences and is accredited to monitor the state of the lakes in Macedonia as well as their biodiversity, water quality and the changes in the ecosystems. Local governmental environmental protection is carried out by local authorities of the Ministry of Environment and Physical Planning.

In Albania, the Ministry of Environment, Forests and Water Administration is responsible for environmental protection measures and acts through various directorates. The ministry cooperates with other ministries on issues related to nature conservation (Strauss and Pezold, 2009). No local institute exists at present on the Albanian side of Lake Ohrid but a new monitoring lab has been established recently. However, most responsible authorities are exclusively based in Tirana.

Legislation concerning conservation and management of natural resources in both countries has been summarized elsewhere (e.g., Watzin et al., 2002; Faloutsos et al., 2006; Strauss and Pezold, 2009).

Major transboundary cooperation on Lake Ohrid conservation issues began in 1998 with the Lake Ohrid Conservation Project (LOCP) (see also Sect. 3.4). The Lake Ohrid Management Board (LOMB) was formed after the signing of the Memorandum of Understanding between the Governments of Albania and Macedonia in 1996. The "Agreement of the Protection and Sustainable Development of Lake Ohrid and its Watershed" between Albania and Macedonia was signed on 17 June 2004 and ratified in 2005 (Faloutsos et al., 2006). This resulted in founding of the Lake Ohrid Watershed Committee (LOWC) with legal authority over the entire Lake Ohrid watershed, i.e. in both countries. The LOWC-secretariat began to work in May 2006 in Ohrid. It provides general support to the LOWC and members from 
both countries (Faloutsos et al., 2006). The bilateral secretariat is one of the organizations concerned with the Strategic Action Plan for management of the Lake Ohrid watershed. It was established in 2008 but is not yet implemented due to financial issues (D. Panovski, personal communication, 2010). The bilateral secretariat is responsible for ensuring the implementation of the major goals of the bilateral "Agreement on Protection and Sustainable Development of Lake Ohrid and its Watershed".

Apart from these official authorities, local nongovernmental organizations (NGOs) such as the Macedonian Limnological Society are concerned with conservation at Lake Ohrid and have been actively involved in the LOCP. "The Green Center" was established in Pogradec, as a centre for coordinating all local NGOs at Lake Ohrid. Initially there were 31 NGOs with 700 members. So far, the number of NGOs has increased to 67 with 2200 members (Panovski and Kekenovski, 2002). The main sources of financing are national budget (grants), membership fees and international grants.

\subsection{Environmental monitoring and ecosystem management}

Macedonia initiated measures to abate the environmental degradation of the lake in the 1980s. Along with these initiatives, legislative regulations have led to a national strategy of permanent environmental monitoring of Lake Ohrid, carried out by the HBI.

Of special concern is sewage treatment. Wastewater is pumped along the shore through a $25.4 \mathrm{~km}$ long collector system into a plant near Struga from where it is discharged into the River Crni Drim. Lack of funding suspended the construction of the collecting system in the late 1980s (GEF, 1997). In two additional construction phases, $44 \mathrm{~km}$ of sewers, which will treat most of the shoreline on the Macedonian side of the lake, will be added to the system (UNESCO ROSTE, 2004).

A General Management Plan for the Ohrid and Prespa region was prepared by the UNESCO Commission in collaboration with the Ministry of Environment and Physical Planning Skopje. The plan passed the governmental procedures and was ratified by parliament.

There is also progress on the Albanian side, for example, a new sewage treatment system has been installed for parts of Pogradec and the surrounding settlements. Less progress has been achieved by the LOCP in the context of establishing sustainable agricultural and forestry practices.

\subsection{Parks and reserves}

On the Macedonian side, UNESCO declared Lake Ohrid and the surrounding area as "Natural and Cultural Heritage of the Ohrid region" in 1979/1980 (Fig. 3). This has been a major step towards international and national recognition of the natural treasures of Lake Ohrid. It is planned to extent this to the whole lake watershed (Faloutsos et al., 2006).

The National Park Galicica was declared in 1958 and covers an area of $25000 \mathrm{ha}$. The park is subdivided in 3 different zones, i.e. strictly protected, tourism recreational, and commercial zones (Fig. 2k). The shoreline cliffs and rocks between Gradishte and Lubanishta on Lake Ohrid as well as the Sv. Naum spring complex are strictly protected (Fig. 3). However, the lake water bodies currently do not belong to the National Park. The National Park opened a modern information center quite recently (November 2009).

Another national park, the transboundary Prespa Park was established in February 2000, in Aghios Germanos, Greece (Fig. 3). It covers both Prespa lake basins and thus is also significant for Lake Ohrid, given the tight hydrological connection between the two lake systems. The idea of creating a UNESCO Biosphere Reserve was implemented in the bilateral agreement signed in 2004. Major reservations against the scheme, however, exist, mainly on the Greek side (UNESCO ROSTE, 2004).

\subsection{Biodiversity and species measures}

The Convention on Biological Diversity (CBD) was ratified in 1998 whilst Albania accessed in 1994. The status of various international environmental agreements in Albania and Macedonia is summarized in Faloutsos et al. (2006).

A first national study on the biodiversity of Macedonia (First national report) was published in 2003 (Ministry of Environment and Physical Planning, 2003). This report comprehensively lists organisms occurring in Macedonia and also includes the Lake Ohrid flora and fauna. Red listings are planned for various taxa, but only preliminary data sets exist for a few selected taxa.

There are conservation activities for particular Lake Ohrid species, most notably for fish. A fishing ban has been in place in Macedonia since 2004 and until 2014 (fishery law, article 24). Since 2003, the state law on fisheries in Albania prohibit fishing during the spawning period only, i.e. no restrictions exist for the rest of the year on the Albanian side of Lake Ohrid (Z. Spirkovski, personal communication, 2010).

Major efforts aim at spawning Ohrid trout at the HBI Ohrid (financed by the Agriculture Ministry). One of the major goals is to yield sustainable populations in the lake (Fig. 2j). According to a recent conservation assessment of the native fish fauna (with a total of 20 species) using IUCN criteria, 1 species is critically endangered, 5 species are endangered and 4 species are vulnerable (Talevski et al., 2010).

Species recovery activities for particular species in Lake Ohrid have been occasionally carried out or planned. One such example is the habitat revitalization of the endangered yellow water lily (Nuphar lutea) in Lake Ohrid, financed by the UNDP and carried out by the Macedonian Limnological Society from 2006 to 2008 . 


\subsection{International activities}

There are international activities concerned with conservation issues, the most outstanding and influential of which has been the bilateral Lake Ohrid Conservation (LOCP) GEF Project (Albania/Macedonia). The World Bank financed the Lake Ohrid management project from 1999-2004 with US \$4.4 Mio. The Swiss government and the German KfW Bank have also been involved (UNESCO ROSTE, 2004). Smaller projects are concerned with particular management and monitoring issues in the transboundary watersheds of Macedonia, Albania and Montenegro. An example is the preparation of the EU Water Directive for the lake. Developing biological tools for monitoring of Lake Ohrid according to the European Waterframe Directive (EWFD) is a trilateral project (2009-2011) of partners from Albania, Macedonia and Norway, intending to establish permanent monitoring of Lake Ohrid according to the EWFD. Other such projects have included the DRIMPOL Project (2003-2005) and the DRIMON Project (2006-2009).

Further EU conservation programs are not yet implemented, for example, within the Natura 2000 network (Emerald network in non-EU countries). National initiatives, however, exist in both Albania and Macedonia.

IUCN Red Listings are available for Lake Ohrid fishes (Kottelat and Freyhof, 2007) and charophytes (Trajanovska, 2009). According to the latter author, $13 \%$ of the total 15 Charophyta species are considered critically endangered, $7 \%$ are endangered, $27 \%$ are in the vulnerable group, $13 \%$ are data deficient, while most of the species (40\%) belong to the low risk group. For other taxa, in particular endemic invertebrates, such assessments do not currently exist. For molluscs, however, an assessment was released (Albrecht et al., 2010²).

\subsection{Research on conservation and raising of public awareness}

There is currently little research devoted to conservation at Lake Ohrid. Notable exceptions include the spawning and release program for the Ohrid trout (Spirkovski and Ilic-Boeva, 2004). There is lack of knowledge of ecology and distribution as well as current population states for basically all invertebrates. Molluscs might be a notable exception (e.g., Hauffe et al., 2010). Research into protection strategies for particular habitat types and vulnerable species is required. Far more research should be conducted regarding the impact of climate change on the ecosystem, species communities and single species.

Research in sustainable agriculture, forestry, and tourism is currently either underrepresented or non-existent. However, the need for ecotourism in the Ohrid Prespa region has been proposed several times (e.g., Grazhdani, 2010).

\footnotetext{
${ }^{2}$ Albrecht, C., Hauffe, T., and Schreiber, K.: unpublished data, 2010 .
}

An international symposium on the protection of natural lakes in Macedonia highlighted the urgency of coordinated conservation measures for Lake Ohrid (Guseska et al., 2007). It is well known to officials that conservation efforts can only be successful when local people are involved and are aware of the natural treasures of their home region. The environmental issues of Lake Ohrid thus are regularly covered by local and regional media. Local schools regularly undertake excursions and perform dedicated projects in order to raise awareness among pupils (D. Georgiev, personal communication, 2010). Several websites nowadays inform about environmental issues at Lake Ohrid. The Museum of Struga Nikola Nezlobinski - has a biological department and an exhibition on Lake Ohrids nature. However, since Ohrid town lacks a similar institution, the establishment of a permanent public museum devoted to Lake Ohrid is under consideration. An agreement between the Lake Biwa Museum (LBM) and the HBI Ohrid to be signed in summer 2010 represents an initial step towards the establishment of such a museum.

Increasing the public awareness was the 4th component of the Lake Ohrid Conservation Project. Public involvement was achieved through contracts with the NGOs of both countries. Increased public awareness resulted, for example, in the establishment of the "Green Center" in Pogradec or the adoption of the 21 June as "Day of Lake Ohrid" (Faloutsos et al., 2006).

\subsection{Conservation needs and challenges to conservation efforts}

Major bilateral efforts, internationally funded like the Lake Ohrid Conservation Project (LOCP), have attempted to stabilize and even improve the situation of Lake Ohrid. Whereas these efforts are, without doubt, necessary to protect one of the greatest treasures of Lake Ohrid - its unique biodiversity - they may not be sufficient to halt the creeping biodiversity crisis in the lake. The principal problem of, for example, endemic invertebrate taxa in Lake Ohrid is that many of them are restricted to small areas within the lake basin. Ongoing surveys of the benthic invertebrate faunas in the Ohrid basin have identified several so-called biodiversity hotspots. One of the most important ones is situated along the karstic eastern shore of the lake - Veli Dab (Albrecht and Wilke, 2008; Hauffe et al., 2010). Other hotspots are, e.g., the littoral near Sveti Zaum, the feeder spring complex at Sveti Naum and its sister complex Tushemisht/Zagorican in Albania (Albrecht and Wilke, 2008).

Whereas anthropogenic effects are noticeable all around the lake, human impact on these biodiversity hotspots could have grave consequences. A destruction of, e.g., habitats around Veli Dab could lead to a permanent loss of $>10 \%$ of the lake's biodiversity (Wilke and Albrecht, 2007). It is therefore advisable to concentrate on habitat related conservation activities when long-term survival of endemic biodiversity is targeted. 
Table 3. Conservation concerns and associated major threats as well as suggested conservation and research needs for Lake Ohrid. Note that the suggested conservation measures and research needs are only examples of the most obvious needs. Most often different needs would apply for each of the mentioned major threats, which sometimes result from multiple sources. For details on the major threats identified for each concern, refer to Table 2.

\begin{tabular}{|c|c|c|c|}
\hline Conservation concern & Major threats & Suggested conservations measures & Research needs \\
\hline \multirow[t]{4}{*}{1 Watershed impacts } & Nutrient input & Significant reduction of nutrient load & $\begin{array}{l}\text { Identification of sources and } \\
\text { processes related to nutrient influx }\end{array}$ \\
\hline & Increased sediment load & e.g., re-diversion of Sateska river & $\begin{array}{l}\text { Monitoring of amount and } \\
\text { fluctuation of sediment loads }\end{array}$ \\
\hline & Waste water & $\begin{array}{l}\text { Implementation of effective waste } \\
\text { water collection and treatment systems }\end{array}$ & GIS-based water management system \\
\hline & Metal contamination & $\begin{array}{l}\text { Stop of any further contamination related } \\
\text { to active and former mining and other industrial facilities }\end{array}$ & Extent and impact of these contaminations \\
\hline \multirow{5}{*}{$\begin{array}{l}2 \text { Agriculture and } \\
\text { forestry }\end{array}$} & Intensified agriculture & Extensive agriculture & GIS-based land use model of the Ohrid basin \\
\hline & Irrigation & Effective water management plan & Implementation of a sustainable agriculture \\
\hline & Logging & Sustainable forestry & Sustainable forestry plan \\
\hline & Water abstraction & $\begin{array}{l}\text { Reduction of water abstraction } \\
\text { (particularly in the Prespa basin) }\end{array}$ & Modelling water balance of the whole watershed \\
\hline & Fire events & Reduction of the frequency of fire events & $\begin{array}{l}\text { Impact of fire events on the terrestrial } \\
\text { and aquatic ecosystems of the Ohrid basin }\end{array}$ \\
\hline \multirow[t]{3}{*}{$\begin{array}{l}3 \text { Tourism and } \\
\text { population growth }\end{array}$} & $\begin{array}{l}\text { Construction of houses } \\
\text { and facilities }\end{array}$ & $\begin{array}{l}\text { Strict regulations and enforcement, establishment } \\
\text { of Coastal Zone Management areas (CZM) and of } \\
\text { Core Conservation areas (CCA) }\end{array}$ & Monitoring, impact studies \\
\hline & $\begin{array}{l}\text { Speed boats } \\
\text { water scooters etc. }\end{array}$ & $\begin{array}{l}\text { Partial ban, regulation of any traffic, } \\
\text { allowance of electro engines only }\end{array}$ & Impact studies \\
\hline & Pollution & $\begin{array}{l}\text { Implementation of effective waste water } \\
\text { collection treatment systems }\end{array}$ & $\begin{array}{l}\text { Fine-scaled identification and monitoring } \\
\text { of all sources for pollution }\end{array}$ \\
\hline \multirow[t]{2}{*}{$\begin{array}{l}4 \text { Non-indigenous } \\
\text { species }\end{array}$} & Competition for native species & $\begin{array}{l}\text { Stop intentional introductions, } \\
\text { stricter control system for fishing activities }\end{array}$ & Monitoring, fine-scaled ecological studies \\
\hline & Community changes & $\begin{array}{l}\text { Establishment of Coastal Zone Management areas (CZM) } \\
\text { and of Core Conservation areas (CCA) }\end{array}$ & Surveys, fine-scaled ecological studies \\
\hline \multirow[t]{4}{*}{$\begin{array}{l}5 \text { Habitat alteration } \\
\text { or loss }\end{array}$} & Destruction coastal habitat & $\begin{array}{l}\text { Stop of any new construction along pristine shorelines, } \\
\text { restoration of habitats such as former adjacent wetlands }\end{array}$ & $\begin{array}{l}\text { Restoration ecology studies, fines-scaled mapping } \\
\text { using satellite and remote sensing approaches }\end{array}$ \\
\hline & $\begin{array}{l}\text { Fragmentation of macrophytic } \\
\text { littoral communities }\end{array}$ & $\begin{array}{l}\text { Establishment of Coastal Zone Management areas (CZM) } \\
\text { and of Core Conservation areas (CCA) }\end{array}$ & $\begin{array}{l}\text { Conservation area science, } \\
\text { GIS-based landscape ecological studies }\end{array}$ \\
\hline & $\begin{array}{l}\text { Spring conversion and } \\
\text { capture in Ohrid Basin }\end{array}$ & $\begin{array}{l}\text { Restoration of captured springs, strict prohibition } \\
\text { of further spring use, conversion or capture }\end{array}$ & Fine-scaled ecological studies, spring monitoring \\
\hline & Eutrophication & $\begin{array}{l}\text { Reduction of pollution, particularly with phosphorus, } \\
\text { water management system (including Prespa basin) }\end{array}$ & Monitoring, modelling \\
\hline $\begin{array}{l}6 \text { Unsustainable } \\
\text { exploitation of fisheries }\end{array}$ & $\begin{array}{l}\text { Overfishing and release } \\
\text { of non-native fish }\end{array}$ & $\begin{array}{l}\text { stricter control and enforcement system } \\
\text { for fishing activities and aqua-cultures }\end{array}$ & Monitoring \\
\hline 7 Global change & Increasing average temperatures & Reduction of climate relevant emissions & Climate impact studies \\
\hline
\end{tabular}

Each of the identified conservation concerns and the associated major threats require particular conservation measures. Given the uncertainty of some of the threats and the restricted knowledge on the complex system and the interplay of the many threats identified, several different strategies are necessary in order to halt or improve the conditions at Lake Ohrid. Some suggested conservation and research needs for Lake Ohrid are listed in Table 3. Most often different needs would apply for each of the mentioned major threats, which sometimes result from multiple sources. For details on the major threats identified for each concern see Table 2.
It is important to recognize that Lake Ohrid has experienced major natural environmental changes and fluctuations throughout its history (e.g., Wagner et al., 2008, 2010; Lindhorst et al., 2010; Vogel et al., 2010b). The magnitude of anthropogenic impact seen in the past years (Vogel et al., 2010a), however, evidently presents a challenging situation for any conservation effort. The complex hydrological setting of Lake Ohrid, such as the long residence time of waters (ca. 70 years, Watzin et al., 2002) and the related response time lag, needs to be considered in an ecosystem-based conservation strategy. 


\section{Conclusions}

Given the number of identified threats to Lake Ohrid, it is clear that only concerted international action can stop or at least slow down further degradation of Lake Ohrid and the creeping biodiversity crisis already evident. Multilateral conservation planning (concerted action plans-CAPs) is necessary. A comprehensive conservation strategy should include measures that result in an immediate reduction of pollution, particularly with phosphorus, in order to slow down the ongoing eutrophication process. A major task is, for example, to re-divert the Sateska River. Overfishing and habitat destruction are other major threats that are well known to have a high impact and urge for immediate regulations. Furthermore, both agriculture and forestry should become sustainable in the whole watershed. The existing watershed management should become more effective.

Implementation, particularly with a view to the enforcement of national laws in Albania and Macedonia, should be enhanced. Envisioning the future integration of both Albania and Macedonia in the European Union, implementation of EU conservation law and strategies such as NATURA 2000 should be prepared. IUCN red listing of the endemic species of Lake Ohrid should continue to be carried out.

Increased research on the lake's limnology, biodiversity, and conservation management practices are necessary. The latter research field should identify conservation priorities. Given the importance of Lake Ohrid as a tourist destination, a sustainable development of tourism (e.g., a ban on private power boats and jet skies, restrictions on import and export of species) is important. Public awareness should be enhanced, including the establishment of a central museum highlighting the importance of Lake Ohrid.

Studies on the least understood but potentially high impact threats such as climate change, pollution with hazardous substances or the role of non-native species are particularly needed. Generally, collaborative scientific studies on ecology, biodiversity and effects of human impact on the whole ecosystem are necessary to enhance the understanding of ongoing processes. This would allow to base any conservation decision on more sound scientific grounds.

Facing the outlined parallel needs to protect the unique biodiversity of Lake Ohrid, we suggest urging (a) implementation and enforcement of the General Management Plan that would ensure long-term integrated and sustainable use of the lake and its watershed, (b) the establishment of Core Conservation areas (CCA), i.e., official reserves with the highest conservation priority, including underwater reserves, and (c) Coastal Zone Management (CZM) areas that would constitute buffer zones for the CCA around the lake.

These activities should, among others, ultimately lead to a trans-boundary major conservation area of the Ohrid-Prespa region that would allow long-term integration of both humans and nature. Such a visionary project could eventu- ally lead to the establishment of a trilateral UNESCO OhridPrespa region Biosphere Reserve.

Acknowledgements. D. Panovski provided information about the LOCP, Z. Spirkovski about fish issues and Z. Angeloski and A. Bojadzi on NP Galicica. Sincere thanks are given to them all.

We particularly thank our dedicated and enthusiastic students and particularly T. Hauffe and K. Schreiber for intense discussions on Lake Ohrid conservation issues. Special thanks go to D. Georgiev for providing valuable background information and Fig. 2b, e, g, h. Colleagues from the HBI have continuously supported our joint efforts in various ways and are here particularly thanked for their support.

CA and TW also wish to thank the German Science Foundation DFG for funding their Lake Ohrid studies (grants AL 1076/3-1 and WI 1902/8-1).

Edited by: B. Wagner

\section{References}

Abell, R.: Conservation biology for the biodiversity crisis: A freshwater follow-up, Conserv. Biol., 16, 1435-1437, 2002.

Albrecht, C. and Wilke, T.: Lake Ohrid: biodiversity and evolution, Hydrobiologia, 615, 103-140, 2008.

Albrecht, C., Hauffe, T., Schreiber, K., Trajanovski, S., and Wilke, T.: Mollusc biodiversity and endemism in the putative ancient lake Trichonis (Greece), Malacologia, 51, 357-375, 2009a.

Albrecht, C., Kroll, O., Terrazas, E. M., and Wilke, T.: Invasion of ancient Lake Titicaca by the globally invasive Physa acuta (Gastropoda: Pulmonata: Hygrophila), Biol. Invasions, 11(8), 1821-1826, 2009b.

Albrecht, C., Hauffe, T., and Schreiber, K.: Red list assessment of Lake Ohrid molluscs, in: IUCN 2010, IUCN Red List of Threatened Species, Version 2010.4., www.iucnredlist.org, last access: 14 December 2010.

Amataj, S., Anovski, T., Benischke, R., Eftimi, R., Gourcy, L. L., Kola, L., Leontiadis, I., Micevski, E., Stamos, A., and Zoto, J.: Tracer methods used to verify the hypothesis of Cvijić about the underground connection between Prespa and Ohrid Lake, Environ. Geol., 51(5), 749-753, 2007.

Avramoski, O., Kycyku, S., Naumoski, T., Panovski, D., Veli, P., Selfo, L., and Watzin, M.: Lake basin management initiative, experience and lessons learned brief: Lake Ohrid, in: Conference "Sharing experience and lessons learned in lake basin management”, Burlington, Vermont, USA, 18-21 June, 2003.

Avramoski, O., Kycyku S., Naumoski, T., Panovski, D., Puka, V., Selfo, L., and Watzin, M.: Lake Ohrid - Experience and lessons learned brief, project report, http://www.ilec.or. jp/eg/lbmi/pdf/19_Lake_Ohrid_27February2006.pdf, last access: November 2010, 321-333, 2006.

Cadotte, M. W., Cardinale, B. J., and Oakley, T. H.: Evolutionary history and the effect of biodiversity on plant productivity, $\mathrm{P}$. Natl. Acad. Sci., 105, 17012-17017, 2008.

Cohen, A.: Extinction in Ancient Lakes: Biodiversity Crises and Conservation 40 Years after J. L. Brooks, in: Speciation in Ancient Lakes, edited by: Martens, K., Gooderis, B., and Coulter, G., Arch. Hydrobiol., 44, 453-481, 1994. 
Cohen, A., Kaufman, L., and Ogutu-Ohwayo, R.: Anthropogenic threats, impacts and conservation strategies in the African Great Lakes - A review, in: The Limnology, Climatology and Paleoclimatology of the East African Lakes, edited by: Johnson, T. and Odada, E., Gordon and Breach Publ., Newark, N.J., USA, 575-624, 1996.

Coulter, G. W., Langenberg, V., Lowe-Mcconnell, R., Riedel, F., Roest, F., Sarvala, J., and Timoshkin, O.: Survival of ancient lake biodiversity, Verh. Internat. Verein. Limnol., 29, 1178-1181, 2006.

Dénèfle, M., Lézine, A.-M., Fouache, E., and Dufaure, J.-J.: First pollen data from Albania: a 12000 years history of lake Maliq, Quaternary Res., 54(3), 423-432, 2000.

Dudgeon, D., Arthington, A. H., Gessner, M. O., Kawabata, Z. I., Knowler, D. J., Lévêque, C., Naiman, R. J., Prieur-Richard, A. H., Soto, D., Stiassny, M. L. J., and Sullivan, C. A.: Freshwater biodiversity: importance, threats, status and conservation challenges, Biol. Rev., 81, 163-182, 2006.

Faloutsos, D., Constantianos, V., and Scoullos, M.: Assessment of the management of shared lake basins in southeastern Europe, GEF IW: LEARN Activity D2, GWP-Med, Athens, 84 pp., available at: http://www.watersee.net/files/ATT00372.pdf, last access: January 2010, 2006.

GEF Global Environmental Facility: Albania and the Former Yugoslav republic of Macedonia Lake Ohrid management project, available at: http://www. iwlearn.net/iw-projects/Fsp_112799468242/project_doc/ lake-ohrid-project-brief-phase-ii-25p-68k.pdf/view, last access: 1 May 2010, 1997.

Genner, M. J., Todd, J. A., and Michel, E.: Resistance of an invasive gastropod to an indigenous trematode parasite in Lake Malawi, Biol. Invasions, 10, 48-49, 2008.

GeoHive: Country - population estimates 2008, http://www.xist. org/cntry/macedonia.aspx and http://www.xist.org/cntry/albania. aspx, last access: November 2010.

Glavin, T.: The sixth extinction: journey among the lost and left behind, Thomas Dunne Books, New York, 2007.

GIWA: Methodology Handbook. Scaling and Scoping, http://www.unep.org/dewa/giwa/methodology/ RevScalScop_Meth_10July2001.PDF, last access: 5 May 2010, 2001.

Grazhdani, D.: Current status of tourism and its opportunities for ecotourism development in the lakes Prespa region, BALWOIS 2010 - Ohrid, Republic of Macedonia, 1-8, 2010.

Guseska, D., Naumoski, T., Mitic, V., Velkova-Jordanoska, L., Stojanoski, S., and Trajanovski, S. (Eds): Proceedings of the I Symposium for protection of natural lakes in republic of Macedonia, Ohrid, Republic of Macedonia, 31 May-3 June 2007, 188 pp., 2007.

Hauffe, T., Albrecht, C., Schreiber, K., Birkhofer, K., Trajanovski, S., and Wilke, T.: Spatially explicit analyses of gastropod biodiversity in ancient Lake Ohrid, Biogeosciences Discuss., 7, 49534985, doi:10.5194/bgd-7-4953-2010, 2010.

Heiler, K. C. M., Nahavandi, N., and Albrecht, C.: A new invasion into an ancient lake - The invasion history of the dreissenid mussel Mytilopsis leucophaeata (Conrad, 1831) and its first record in the Caspian Sea, Malacologia, 53, 185-192, 2010.

Holtvoeth, J., Vogel, H., Wagner, B., and Wolff, G. A.: Lipid biomarkers in Holocene and glacial sediments from ancient Lake
Ohrid (Macedonia, Albania), Biogeosciences, 7, 3473-3489, doi:10.5194/bg-7-3473-2010, 2010.

IUCN: IUCN Red List Categories and Criteria: Version 3.1. IUCN Species Survival Commission, IUCN, Gland, Switzerland and Cambridge, UK, 2001.

Jordanoski, M., Naumoski, T., and Veljanoska, S. E.: Physicochemical investigations of Ohrid and Prespa lake, in: Lake Ohrid and Prespa monitoring Program, 3rd Report, Hydrobiological Institute Ohrid, 09-20, 2004.

Jordanoski, M., Lokoska, L., and Veljanoska, S. E: The river Sateska and consequences of its diversion to Lake Ohrid. BALWOIS, Conference on Water Observation and Information Systems for Decision Support, Ohrid, Republic of Macedonia, http: //www.balwois.com/cms/, last access: January 2010, 23-26 May 2006.

Kostoski, G., Gušeska, D., and Tasevska, O.: Zooplankton investigations, Lakes Ohrid and Prespa Monitoring Program, 3rd Report, Hydrobiological Institute Ohrid, Ohrid, Republic of Macedonia, 45-60, 2004.

Kottelat, M. and Freyhof, J.: Handbook of European Freshwater Fishes, Cornol and Berlin, 646 pp., 2007.

Kuussaari, M., Bommarco, R., Heikkinen, R. K., Helm, A., Krauss, J., Lindborg, R., Ockinger, E., Pärtel, M., Pino, J., Rodà, F., Stefanescu, C., Teder, T., Zobel, M., and Steffan-Dewenter, I.: Extinction debt: a challenge for biodiversity conservation, Trends Ecol. Evol., 24(10), 564-571, 2009.

Lindhorst, K., Vogel, H., Krastel, S., Wagner, B., Hilgers, A., Zander, A., Schwenk, T., Wessels, M., and Daut, G.: Stratigraphic analysis of lake level fluctuations in Lake Ohrid: an integration of high resolution hydro-acoustic data and sediment cores, Biogeosciences, 7, 3531-3548, doi:10.5194/bg-7-3531-2010, 2010.

Lokoska, L., Novesvska, V., and Vasileska, A.: Microbiological investigations of Lake Ohrid, in: Lake Ohrid and Prespa monitoring Program, 3rd Report, Hydrobiological Institute Ohrid, 2332, 2004.

Mankolli, H. and Peculi, V.: Global climate change impacts on Albania: meteorological analysis of Ohrid basin, BALWOIS 2010, Ohrid, Republic of Macedonia, 25-29 May, 2010.

Marijnissen, S. A. E., Michel, E., Cleary, D. F. R., and McIntyre, P. B.: Ecology and conservation status of endemic freshwater crabs in Lake Tanganyika, Africa, Biodivers. Conserv., 18(6), 15551573, 2009.

Matter, M., Anselmetti, F. S., Jordanoska, B., Wagner, B., Wessels, M., and Wüest, A.: Carbonate sedimentation and effects of eutrophication observed at the Kališta subaquatic springs in Lake Ohrid (Macedonia), Biogeosciences, 7, 3755-3767, doi:10.5194/bg-7-3755-2010, 2010.

Matzinger, A., Jordanoski, M., Veljanoska-Sarafiloska, E., Sturm, M., Müller, B., and Wüest, A.: Is Lake Prespa jeopardizing the ecosystem of ancient Lake Ohrid?, Hydrobiologia, 553, 89-109, doi:10.1007/s10750-005-6427-9, 2006a.

Matzinger, A., Spirkovski, Z., Patceva, S., and Wüest, A.: Sensitivity of Ancient Lake Ohrid to Local Anthropogenic Impacts and Global Warming, J. Great Lakes Res., 32, 158-179, $2006 \mathrm{~b}$.

Matzinger, A., Schmid, M., Veljanoska-Sarafiloska, E., Patceva, S., Guseska, D., Wagner, B., Müller, B., Sturm, M., and Wüest, A.: Eutrophication of ancient Lake Ohrid: Global warming amplifies detrimental effects of increased nutrient inputs, Limnol. Oceanogr., 52, 338-353, 2007. 
Ministry of Environment and Physical Planning: Country Study for Biodiversity of the Republic of Macedonia (First National Report), Skopje, 2003.

Moore, M. V., Hampton, S. E., Silow, E. A., Izmest'eva , L. R., Peshkova, E. V., and Pavlov, B. K.: Climate Change and the World's "Sacred Sea" - Lake Baikal, Siberia, Bioscience, 59(5), 405-417, doi:10.1525/bio.2009.59.5.8, 2009.

Noges, P., Kangur, K., Noges, T., Reinart, A., Simola, H., and Viljanen, M.: Highlights of large lake research and management in Europe, Hydrobiologia, 599, 259-276, 2008.

Norris, K. and Harper, N.: Extinction processes in hot spots of avian biodiversity and the targeting of pre-emptive conservation action, P. Roy. Soc. Lond. B Bio., 271, 123-130, 2004.

Panovski, D. and Kekenovski, J.: Lake Ohrid Conservation Project: Model for integrated management of transboundary waters (Presentation), Second International Conference on Sustainable Management of Transboundary Waters in Europe, Miedzyzdroje, Poland, 21-24 April, 2002.

Purvis, A., Jones, K. E., and Mace, G. M.: Extinction, BioEssays, 22(12), 1123-1133, 2000.

Riedel, F., Audzijonyte, A., and Mogue, N.: Aliens associating with Caspian endemic bivalves, Biol. Invasions, 8, 1067-1071, 2006.

Schmieder, K. and Pier, A.: Lakeside reed border characteristics at Lake Constance (Untersee): A comparison between 1981-1983 and 1994, Wetl. Ecol. Manag., 8(6), 435-445, 2000.

Secretariat of the Convention of Biological Diversity: Connecting biodiversity and climate change mitigation and adaptation, Report of the Second Ad Hoc Technical Expert Group on Biodiversity and Climate Change, Montreal, Canada, CDB Technical Series, 41, 127 pp., available at: www.cbd.int/doc/publications/ cbd-ts-41-en.pdf, 2009.

Serafimova, J.: 50 years since the establishment of the hydrobiological institute in Ohrid, A jubilee edition dedicated to the 50th Anniversary of the establishment of the Hydrobiological Institute in Ohrid, Hydrobiological Station Ohrid, 49-75, 1985.

Southeast European Times: Tourists flock to Southeast Europe for holidays, http://www.setimes.com/cocoon/setimes/xhtml/en GB/features/setimes/articles/2007/10/08/reportage-01, last access: November 2010, 2007.

Spirkovski, Z. and Ilic-Boeva, D.: The state of the Lake Ohrid trout and Lake Ohrid Belvica, in: Lake Ohrid and Prespa monitoring Program, 3rd Report, Hydrobiological Institute Ohrid, 7785, 2004.

Stanković, S.: The Balkan Lake Ohrid and its Living World, edited by: Junk, W., Monog. Biol., Den Haag, Netherlands, 9, 357 pp., 1960.

Stift, M., Michel, E., Sitnikova, T. Y., Mamonova, E. Y., and Sherbakov, D. Y.: Palaearctic gastropod gains a foothold in the dominion of endemics: range expansion and morphological change of Lymnaea (Radix) auricularia in Lake Baikal, Hydrobiologia, 513(1-3), 101-108, 2004.

Strauss, A. and Pezold, B. (compilers): All Along the Watchtowers: Field Guide for the Southeastern European Green Belt, IUCN Programme Office for Southeastern Europe, Belgrade, Serbia, 2009.

Strayer, D. L.: Challenges for freshwater invertebrate conservation, J. N. Am. Benthol. Soc., 25, 271-287, 2006.

Sturmbauer, C.: The Great Lakes in East Africa: biological conservation considerations for species flocks, Hydrobiologia, 615,
95-101, 2008.

Supreme Audit Institution: Report On the audit conducted at Ministry of Environement, Forestry and Water administration, on the preservation of Lake Ohrid Project, http://www. eurosaiwgea.org/Environmenta1\%20audits/Water/Documents/ 2007-Albania-Conservation\%20of\%20Lake\%20Ohrid.pdf, last access: 1 May 2010, 2008.

Szymanczak, R., Spirkovski, Z., and Sell, J.: A note on Salmo letnica, the endemic Ohrid Trout, population structuring, Review 42, Special Issue SIAL 5, p. 127, 2009.

Talevski, T., Milosevic, D., and Talevska, A.: Anthropogenic influence and conservation status of authochthonous fish fauna from Lake Ohrid, BALWOIS 2010, Ohrid, Republic of Macedonia, 25-29 May, 2010.

Taylor, W. W. and Gerking, S. D.: Potential of the Ohrid rifle minnow, Alburnoides bipunctatus ohridanus, as an indicator of pollution, Verh. Internat. Verein. Limnol., 20, 2178-2181, 1978.

Thomas, J. A., Telfer, M. G., Roy, D. B., Preston, C. D., Greenwood, J. J. D., Asher, J., Fox, R., Clarke, R. T., and Lawton, J. H.: Comparative Losses of British Butterflies, Birds, and Plants and the Global Extinction Crisis, Science, 303, 1879-1881, 5665, doi:10.1126/science.1095046, 2004.

Thomas, C. D., Cameron, A., Green, R. E., Bakkenes, M., Beaumont, L. J., Collingham, Y. C., Erasmus, B. F. N., Ferreira de Siqueira, M., Grainger, A., Hannah, L., Hughes, L., Huntley, B., van Jaarsveld, A. S., Midgley, G. F., Miles, L., Ortega-Huerta, M. A., Townsend Peterson, A., Phillips, O. L., and Williams, S. E.: Extinction risk from climate change, Nature, 427, 145-148, 2004.

Tocko, M. and Sapkarev, J.: Annual variations of the important zoobenthic populations in Lake Ohrid, Verh. Internat. Verein. Limnol., 20(2), 1090-1095, 1978.

Topi, D., Seitia, B., Halimib, E., and Gjinalic, E.: The Toxic Evaluation of PCBs in Edible Fishes from Ohrid Lake, BALWOIS 2010, Ohrid, Republic of Macedonia, 25-29 May, 2010.

Trajanovska, S.: Taxonomy, ecology and status of the charophyte vegetation (CHAROPHYTA) from Lake Ohrid, Ph.D. thesis, St. Cyril and Methodius University, Faculty of natural sciences and mathematics, Institute of Biology, Skopje, Republic of Macedonia, 2009.

Trajanovski, S.: Structure, dynamic and distribution of the macrozoobenthos from Lake Ohrid with a special view on settlement of the macrophytic vegetation, Ph.D. thesis, St. Cyril and Methodius University, Faculty of natural sciences and mathematics, Institute of Biology, Skopje, Republic of Macedonia, 2005.

Trajanovski, S. and Budzakoska, B.: The qualitative composition of the macrozoobenthos as an indicator for the quality of the water of some littoral parts of Lake Ohrid, 31 Conference of current problems with water supply and protection of waters "Waters 2002", Serbia and Montenegro, Review, 55-160, 2002.

UNESCO ROSTE: Report about the Lake Ohrid watershed region, http://portal.unesco.org/en/ev.php-URL_ID=24220\&URL DO=DO_TOPIC\&URL_SECTION=201.html, last access: 1 May 2010, 2004.

Vogel, H., Wagner, B., Zanchetta, G., Sulpizio, R., and Rosén, P.: A paleoclimate record with tephrochronological age control for the last glacial-interglacial cycle from Lake Ohrid, Albania and Macedonia, J. Paleolimnol., 44, 295-310, doi:10.1007/s10933009-9404-x, 2010a 
Vogel, H., Wessels, M., Albrecht, C., Stich, H.-B., and Wagner, B.: Spatial variability of recent sedimentation in Lake Ohrid (Albania/Macedonia), Biogeosciences, 7, 3333-3342, doi:10.5194/bg7-3333-2010, 2010b.

Von Rintelen, T. and Glaubrecht, M.: Three new species of the freshwater snail genus Tylomelania (Caenogastropoda: Pachychilidae) from the Malili lake system, Sulawesi, Indonesia, Zootaxa, 1852, 37-49, 2008.

Wagner, B., Reicherter, K., Daut, G., Wessels, M., Matzinger, A., Schwalb, A., Spirkovski, Z., and Sanxhaku, M.: The potential of Lake Ohrid for long-term palaeoenvironmental reconstructions, Palaeogeogr. Palaeocl., 259, 341-356, 2008.

Wagner, B., Vogel, H., Zanchetta, G., and Sulpizio, R.: Environmental change within the Balkan region during the past ca. $50 \mathrm{ka}$ recorded in the sediments from lakes Prespa and Ohrid, Biogeosciences, 7, 3187-3198, doi:10.5194/bg-7-3187-2010, 2010.
Watzin, M. C., Puka, V., and Naumoski, T. B. (Eds.): Lake Ohrid and its watershed, state of the environment report, Lake Ohrid Conservation Project, Tirana, Republic of Albania and Ohrid, Republic of Macedonia, 2002.

Wilke, T. and Albrecht, C.: How to stop the creeping biodiversity crisis in Lake Ohrid? Suggestions for sustainable conservation strategies of biodiversity hotspots, in: Proceedings of the I Symposium for protection of the natural lakes in Republic of Macedonia, Ohrid, Republic of Macedonia, 31 May-3 June 2007, 44-45, 2007.

Wilke, T., Schultheiß, R., Albrecht, C., Bornmann, N., Trajanovski, S., and Kevrekidis, T.: Native Dreissena freshwater mussels in the Balkans: in and out of ancient lakes, Biogeosciences, 7, 3051-3065, doi:10.5194/bg-7-3051-2010, 2010. 